\title{
14
}

\section{Energy, Capital as Power and World Order}

Until late, the subject of energy and its importance for capitalism and the 4 constitution and reconstitution of world order has been sorely overlooked 5 in the international political economy (IPE) literature. Indeed, only two of 6 the major textbooks in IPE have chapters on energy (Di Muzio and Ovadia 7 2016). This is also true of the literature known as classical political economy. 8 With few exceptions, the main questions that animated the classics such as 9 the origins of the wealth of nations and the distribution of wealth are some- 10 how disconnected from the production and consumption of energy. Marginal 11 exceptions granted, there is little acknowledgement that the last three centu- 12 ries of uneven and combined "progress" and "development" have anything 13 to do with the exploitation of coal, oil and natural gas. However, if recent 14 scholarship is any indication, this appears to be changing both within IPE 15 and within other academic fields such as geography, sociology and environ- 16 mental studies. In this emergent literature, we can find an argument that 17 energy should not be treated as auxiliary to our analysis of the global politi- 18 cal economy but essential to understanding and interpreting its emergence, 19

[AU2] transformations and future trajectories (Di Muzio 2015). Since fossil fuels 20 make up an overwhelming share of global energy production and consump- 21 tion (see Fig. 14.1) I will mainly concentrate of non-renewable fossil fuels and 22

T. Di Muzio $(\bowtie)$

International Relations and Political Economy, University of Wollongong Australia, Wollongong, NSW, Australia

(C) The Editor(s) (if applicable) and The Author(s) 2016 


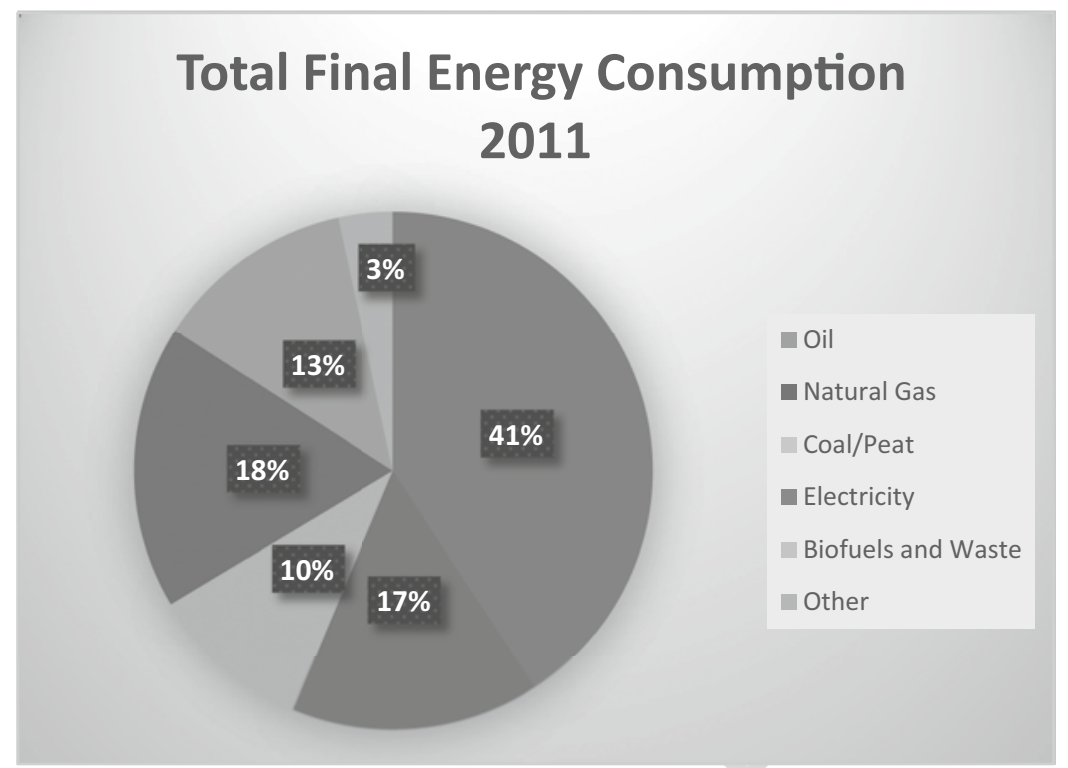

Fig. 14.1 Total final energy consumption, 2011

aim to provide a critical political economy approach to energy, capitalism and world order by using the capital as power perspective.

This is certainly not the only approach that we could take, but it is the one I find most revealing and convincing. To make this argument, I have divided the article in the following way. First, I concisely survey why energy is important for our theorizations of the global political economy as well as for understanding the practices of everyday life. With this background information in place, I briefly review how mainstream and critical accounts have approached the question of energy and the global political economy and demonstrate how the capital as power approach is distinctive for its focus on capitalization and social reproduction. In the second section, I will consider the power of the oil and gas firms in shaping and reshaping social reproduction and how there are strong indicators to suggest that renewable forms of energy cannot presently_and likely never will-replace fossil fuels and perpetuate energy intensive modes of living centuries into the future. Moreover, because of the entrenched power of oil and gas firms and their connection with affluent social reproduction, transitioning to less carbon intensive modes of social reproduction are being stalled. I conclude the article by discussing the relationship between energy, violence and world order. 


\section{A Brief Excursus on Energy}

[AU3] Though often taken for granted in daily life, if we take energy seriously, the global political economy is at base a solar economy whereby humans have come to monetize energy and natural resources in hierarchical domestic and international relationships. Without the energy of the sun and the conversion of radiant energy into chemical energy carried out by plants and algae through the process of photosynthesis, life on earth would be impossible. Oil, coal and natural gas — can be considered "buried sunshine", or chemical stores of energy that, through heat and pressure over millennia, have accumulated in variegated reservoirs internationally (Crosby 2006). These fossil fuels are ultimately derived from the energy of the sun and are understood to be nonrenewable on a human scale. But what is energy and what is at stake in taking it seriously? Natural scientists may debate the precise definition of "energy" but most would agree that it can be conceptualized as the capacity to do work (Smil 1994, 2006). What this suggests is that political economies with more energy have a greater potential to do work on the natural environment and transform their conditions of existence-albeit within a network of power relations and historical constraints and enablers. Indeed, countries that are considered "advanced economies" or "highly developed" political communities will show very high energy consumption figures while those considered as lesser or least developed countries will show very low energy consumption figures. Figure 14.2 charts the total primary energy consumption of three least developed countries recognized by the World Bank.

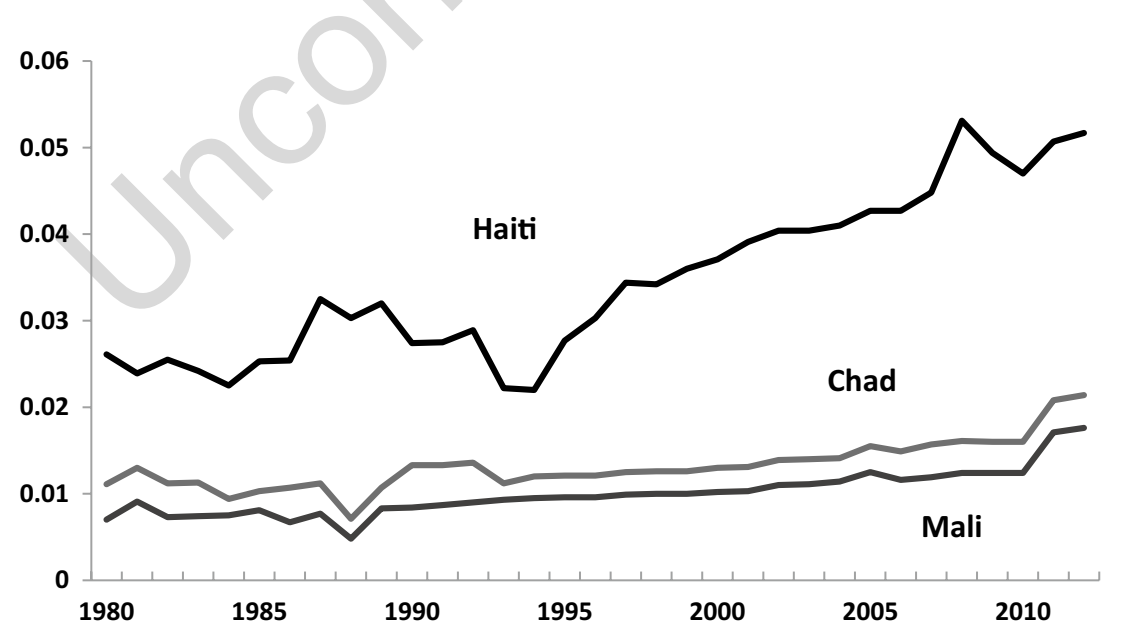

[AU4] Fig. 14.2 Total primary energy consumption, LDCs, quadrillion btus, 1980-2012 
All three countries are consuming very low amounts of energy and do not even approach one quadrillion British thermal units. This disparity in energy access and therefore productive ability becomes apparent when considering Fig. 14.3 which charts energy consumption from three internationally recognized "developed" countries. The difference in the orders of magnitude is unmistakable. Fig. 14.4 also contrasts the energy use per capita between the two groups of countries. Thus on an aggregate and per capita basis, developed countries simply consume in order of magnitude more energy than least developed countries.

What these charts strongly suggest is that one of the things at stake in taking energy seriously for critical IPE scholars is the recognition that radically uneven consumption and access to energy should be a key factor in explaining the persistence of poverty and "underdevelopment". As the United Nations Development Programme (UNDP) noted:

Energy services are a crucial input to the primary development challenge of providing adequate food, shelter, clothing, water, sanitation, medical care, schooling, and access to information. Thus energy is one dimension or determinant of poverty and development, but it is vital ... lack of access to energy contributes to poverty and deprivation and can contribute to economic decline. (2000:44)

But the connection between access to affordable energy and development is not the only thing at stake in taking energy seriously. Four additional concerns can be highlighted before we move on to discuss how mainstream

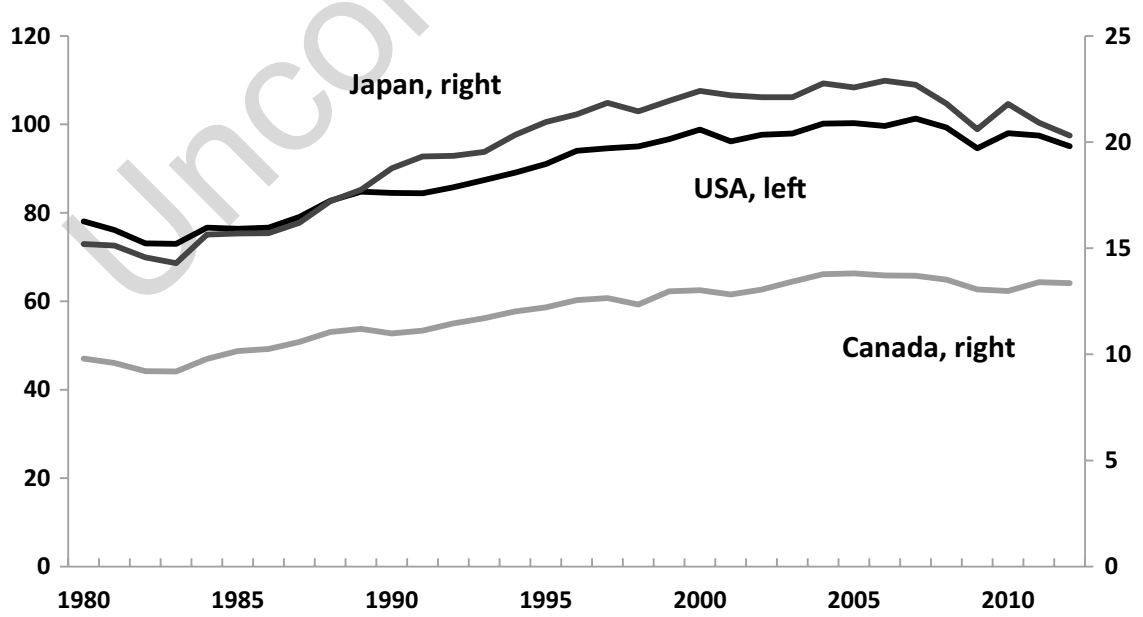

Fig. 14.3 Total primary energy consumption, quadrillion btus, 1980-2012 


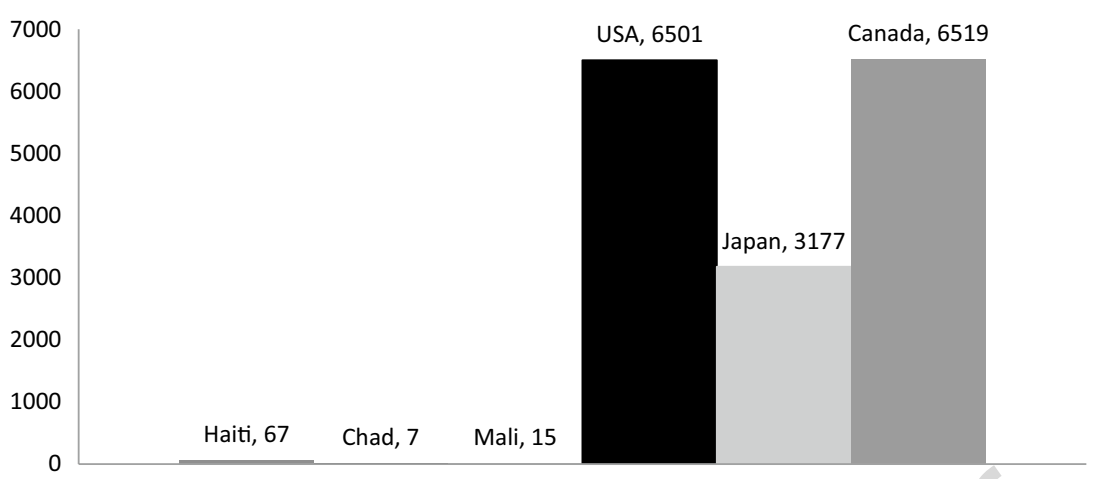

Fig. 14.4 Energy consumption per capita, 2010. Source: UNDATA

and critical scholarships have approached the global political economy of 87 energy. First, for energy to be useful, it must be converted into another 88 form. However, energy conversion is never a straightforward process as some 89 energy is always lost in the transformation and not all energy can be con- 90 verted easily. Second, the ratio of energy returned on the energy invested or what is known as ERoEI, is a crucial indicator of how much energy needs to be consumed or invested in return for a specific amount of energy received. A declining ERoEI is worrisome in an energy dependent economy because it suggests that it is becoming more difficult and expensive for firms to harness energy resources. Third, the global combustion of fossil fuels is the leading cause of global climate change and if companies and consumers continue to monetize and combust the world's remaining stores, the climate future generations inherit will be radically changed. As the former head of NASA's Goddard Institute for Space Studies, James Hansen and his colleagues warned "burning all fossil fuels would threaten the biological health and survival of humanity, making policies that rely substantially on adap[AU6] tation inadequate" (James Hansen et al. 2013: 25). In sum, the ongoing social reproduction of high-energy lifestyles is effectively destroying the biosphere for future generations, the consequences of which will be experienced unevenly across the global population (Kempf 2008; Di Muzio 2015a). Last, from an evolutionary perspective, we could also make the argument that over time, certain human communities-for one reason or another-have become more proficient at capturing and converting energy for the social reproduction of energy intensive modes of living. But critical political economists cannot stop at this level of conceptualization and must understand the production and consumption of energy within the context of historical and shifting power relations. 91 92 93 94 95 96 97 98 99 100 101 102 103 104 105 106 107 108 109 110 111 112 113 


\section{Mainstream and Critical Approaches}

In IR/IPE there are two mainstream approaches to energy: (neo)realist and neolilberal institutionalism and a variegated critical approach mainly informed by the Marxist tradition. ${ }^{1}$ All have something to offer the debates in IPE but the mainstream approaches are fairly narrow-minded and insufficiently critical while the Marxist approach has serious flaws insofar as it rests on the labour theory of value. Speaking broadly, most realists fetishize the state and conceive of it as though it was a unitary actor operating in an anarchical system. Because there is no world government to hold states in check, realists argue that statesmen and women must do their best to protect the nation's security. Having access to fossil fuels - and energy more generally-in this framework is useful only insofar as it can help maximize the power and security of the state as a whole. In this state-centric approach there is very little analysis of who exactly benefits from war and fossil fuel dependence or why energy consumption is so uneven. Most realists lump energy/ oil under 'material capabilities' (as do some critical scholars, e.g. Cox 1987) and assume that the amount or quality of these capabilities are linked with international power or the lack of it. However, because "material capabilities" are never conceptually unpacked, access to fossil fuels is treated just like access to any other strategic commodity. Others are more explicit and focus on how international power is underwritten by access to fossil fuels (particularly oil) and investigate how energy and international conflicts are related in past, present and the likely future (e.g. Colgan 2013a and b; Elhefnawy 2008; Friedrichs 2013; Klare 2002, 2004, 2009; Sprio 1999; Stoddard 2013; Stokes and Raphael 2010).

The approach of neoliberal institutionalism is generally concerned with how agents other than the state can help promote transnational cooperation and overcome international anarchy-largely by rules, institutions and market mechanisms (Colgan et al. 2012; Goldthau and Witte 2013; Ikenberry 1986; Keohane 1978; Keohane and Victor 2013). In general, most neoliberal institutionalists take capitalism for granted and demonstrate very little awareness of how the magnitude of capital accumulation and its greater universalization is historically tethered to the exploitation of non-renewable fossil fuels. Indeed, the neoliberal institutionalist approach is far more interested in problem solving than it is in understanding how the present world order emerged. Moreover, the liberal tradition tends to have a progressive understanding of history that anticipates continued economic growth and

${ }^{1}$ A useful summary is found in (Hancock and Vivoda 2014). 
human betterment (Di Muzio 2011; Jahn 2013). This is despite the fact that 151 there are very real physical limitations to perpetual economic growth (Fix 152 [AU8] 2014).

From a critical point of view, Marxists fare much better than their main154 stream counterparts. Marx was certainly aware of humanity's inseparable tie with nature. However, in his scientific account of capitalism, he treated labour as the sole source of value and relegated the major energy source of his timecoal - to an "auxiliary" in production. From this point, energy remained a key blind spot for Marxism until the oil price shocks of the 1970s. The work of (Debeir et al. 1991) underscored the importance of energy for Marxist political economy but their work was virtually ignored until late. With few exceptions (Bromley 1991; Nore and Turner 1980), it was not until the oil price spike of 2000, the "war on terror" and murmurs about peak oil that Marxist attention resurfaced on questions related to energy, political economy and international power and imperialism. I cannot do justice to the richness of these works here and they are certainly more critical and insightful than the mainstream approaches (e.g. Altvater 2007; Bromley 1991, 2005; Podobnik 2006). However, with some nuance, what they all share in common is the view that capitalism is a mode of production and (implicitly or explicitly) that labour power is the sole source of value and that labour time can somehow explain prices and accumulation (the transformation problem). As I see it there are at least two problems with this position, (1) for the most part it is only concerned with production and therefore misses wider societal aspects of power and how they impact upon accumulation and; (2) it is far more likely that corporate power and control over production shapes prices and accumulation rather than labour time values. For these reasons I use what is arguably the more critical approach of capital as power.

The capital as power approach differs in a number of important ways from the perspectives we have only briefly discussed (Nitzan and Bichler 2009; Di Muzio 2014). First, capitalism is conceived not as a mode of production between workers and capitalists but as a mode of power between owners or capitalists and non-owners. The primary act of owners is the capitalization of income-generating assets with the goal to accumulate more money at a faster pace than rivals attempting to do the same. The dominant actor is understood to be the corporation or firm and those with the highest levels of capitalization are theorized as "dominant capital" or those firms with the power to shape and reshape social reproduction more effectively than firms with smaller capitalization. Accumulation in this framework is measured by how much the value of an owner's capitalization rises over time with the level of capitalization largely contingent on the earnings firms are able to generate. 
191 From the point of view of the capital as power approach, earnings are not sim192 ply a matter of producing commodities for the market and the exploitation 193 of workers. Earnings are a matter of a firm's ability to exert material, cultural and ideological power of an entire social field and the more successful they are in doing so the greater their differential earnings will be relative to rival accumulators in the corporate universe. For this reason, capital is not theorized as "capital goods" as in the neoclassical approach nor is it understood to be 'dead labour' as in the Marxist approach. Instead, capital is theorized as commodified differential power. What this means is that when investors or owners hold or purchase claims to income-generating assets, they are effectively capitalizing the power of a corporation to shape and reshape the terrain of social reproduction. Briefly, social reproduction can be understood as the way in which any society produces, consumes and reproduces its lifestyles and livelihoods, how it understands them and how it justifies these practices both ideologically, legally and by an apparatus of force and punishment (e.g. military, prisons, detention camps). What this suggests is that the state or government apparatus can never be dislocated or disentangled from the process of accumulation. There are two main ways in which the state and capital are intimately connected. First, most governments in the world have a "national" debt that is owned by private capitalists and who receive interest payments on their securities from the tax and fine revenues generated by governments. In other words, the state or government apparatus is itself a capitalized entity. Second, the market for government debt or perhaps more simply, the bond market, is the heart of global finance because it provides a benchmark rate of return for capitalists to assess or evaluate their investment priorities. Insofar as interest rates remain positive, it provides owners with a guaranteed return on investment. For these reasons the capital as power approach does not theorize the state and market or the state and corporation as practically or ideologically separate. Instead, political and corporate power have always been fundamentally entangled, albeit in a variety of ways we cannot fully discuss in this brief chapter. But while all these points may be intelligible to readers, it remains for us to highlight how the capital as power perspective is a critical approach to political economy. First, the accumulation of money is not based on individual productivity or the contributions one makes to society but rooted in the institution of ownership and ownership largely originated in past violence, access to political power and legal fiction. Second, private ownership of income-generating assets implies both exclusion and the sabotage or damage of society and human creativity. There are two types of sabotage: general and specific. General sabotage implies that all firms must engage in some degree of incapacitation in trying to accumulate differentially. Specific 
sabotage is the way in which each individual firm strategically acts to disrupt or incapacitate production and the wider process of social creativity. Third, 231 the capitalist mode of power follows the logic of differential accumulation, a logic that is based on increasing inequality and non-democratic forms for exclusion at the expense of pursuing a more humane logic that would have decent human livelihoods, the alleviation of gross inequalities, and the protection of the biosphere as its focus. In the next section, I apply the capital as power framework to the largest sector in the global economy by market capitalization.

\section{Capitalism and the Power of Oil and Gas Firms}

If we conceive of the global political economy analytically, we could argue 241 that it is made up of 37 sectors ranked by market value or capitalization. ${ }^{2}$ At first glance, it would appear that banks lead all the other sectors at US\$4.5 242 trillion in market capitalization. Intuitively, this would seem to make sense 243 given the importance of money in a market economy and the way that money 244 expands largely through commercial bank loans. However, this is illusory. By 245 far the most capitalized industry on the planet is the oil and gas industry once the estimated market value of state owned oil and gas firms are considered. In 2005 McKinsey valued the state oil and gas firms as if they were publicly traded companies and imputed (adjusted for inflation) a figure of about US\$3.6 trillion. If we add this sum to the capitalization of oil and gas firms in the 2014 edition of the FT Global 500-a list of the largest companies in the world by market value - the total capitalization for the oil and gas sector would be US\$6.7 trillion. As part of the unholy trinity of fossil fuels, if we added coal to the figure, we would witness a negligible increase since the total market value according to Stowe's coal index is US\$115 billion. ${ }^{3}$ But what does all this suggest? First, it suggests the absolute centrality of oil and gas to the formation and reformation of what I have previously called a global [AU9] petro-market civilization (Di Muzio in Gill 2011; Di Muzio 2012, 2015b). I theorize this as an uneven and hierarchical civilizational order whose social reproduction of energy intensive living is largely contingent on affordable, accessible and abundant carbon energy. What this implies is that for a significant portion of humanity, previous stores of solar energy are being monetized to promote high-energy lifestyles_or what Brand and Wissen (2013) refer

${ }^{2}$ The following draws on the Global FT 500.

${ }^{3}$ http://stowe.snetglobalindexes.com/ (4/3/2015). 
to as an "imperial mode of living". However, since we know that wealth and income are highly uneven both within and between nations, it also suggests that the small fraction of humanity with more income and wealth are also those responsible for greater environmental damage and the potential destruction of a habitable biosphere for future generations and non-human species. As Barry sombrely notes: "the scientific evidence for anthropogenic climate change has accumulated to the extent that we could be the first species to accurately document our own demise" (2012: 1). This is indeed a sobering thought given that the second reason why realizing that the oil and gas sector is the most heavily capitalized is important: the future. When investors purchase shares in corporations they are capitalizing the corporation based on expected future profit, not present performance. What this means is that the level of capitalization relative both to past capitalization of the firm and other firms in the corporate universe is a forward looking indicator for how investors think about the future. Rising capitalization relative to past capitalization as well as relative to rival accumulators suggests that investors see a bright future for meeting projected earnings targets. Now, it goes without saying that investors are often wrong about the future, but the danger of being incorrect does not stop them from trying to anticipate likely futures based on the information they have to hand. Figure 14.5 plots the capitalization of all the major oil and gas firms listed on the FT Global 500.

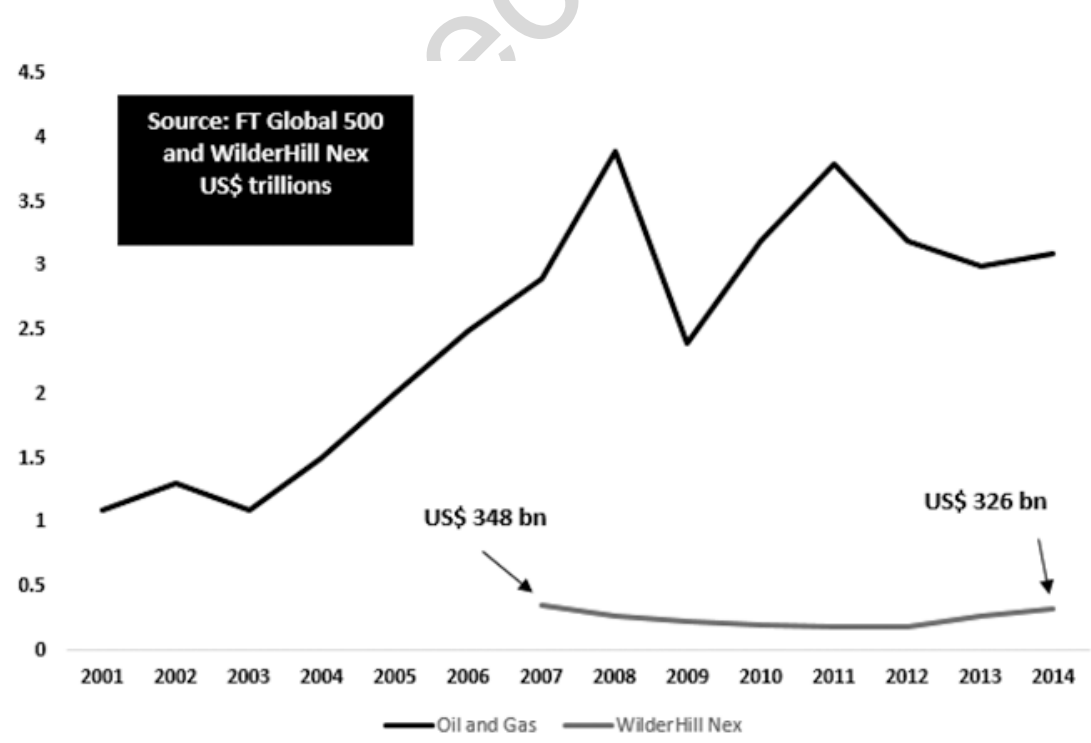

Fig. 14.5 Oil and gas company capitalization vs WilderHill NEX, 2001-2014 


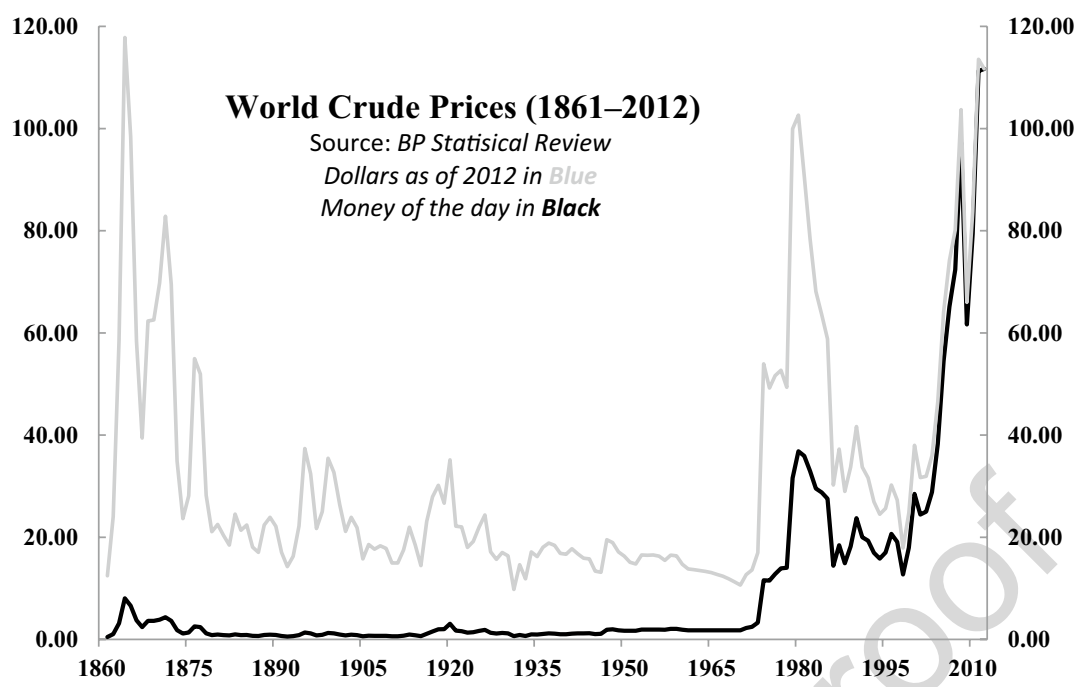

[AU11] Fig. 14.6 World crude prices, 1861-2012

Despite the dip during the global financial crisis in 2008-9, the trend is clear. The capitalization of the oil and gas firms increased by $182 \%$ from the 286 beginning to the end of our period. Thus, if we created an equally weighted 287 basket of oil and gas stocks on the FT Global 500 and paid US\$1,000 to 288 purchase our shares in 2001 at the start of our period, we would have earned 289 US $\$ 1,820$ by 2014 . One can imagine the astronomical sums made by those 290 who own millions of shares in oil and gas companies rather than our pal291 try example of having simply invested US\$1,000. But Figure 14.5 suggests 292 something even more important since it also plots the most comprehensive 293 index for the renewable energy industry - the WilderHill New Energy Global 294 Innovation Index or in brief NEX. ${ }^{4}$ Now there is little doubt that since at least 295 the turn of the 21 st century considerably more attention has been given to 296 finding, funding and subsidizing renewable energy. This drive heightened as 297 the price of oil skyrocketed over the period (see Fig. 14.6) leading to renewed 298 and in some sense greater calls for energy independence and alternatives to 299 fossil fuels.

\footnotetext{
4 "The WilderHill New Energy Global Innovation Index is comprised of companies worldwide whose innovative technologies and services focus on generation and use of cleaner energy, conservation and efficiency, and advancing renewable energy generally. Included are companies whose lower-carbon approaches are relevant to climate change, and whose technologies help reduce emissions relative to traditional fossil fuel use".http://www.nexindex.com/ (3/24/2015).
} 
Institutionalizing this trend, a new intergovernmental body-the International Renewable Energy Agency (IRENA) - came into force in 2010 in Abu Dhabi. IRENA is headquartered in Masdar City, a multi-billion dollar arcology project in the process of building a planned city with sustainable elements, including the use of renewable energy and pedestrian friendly public transport networks. There are other positive signs that the newly emergent renewable energy industry may eventually help substitute for, if not by some accounts, totally replace (over time) the consumption of oil and gas. For instance, the latest report from the Renewable Energy Policy Network for the 21 st Century celebrated the fact that 144 countries had demonstrated some commitment to meeting renewable energy targets while 138 countries had policies in place to support the renewable energy industry (REN21 2014). While investments fluctuate yearly, the same report also notes that investment in the hundreds of billions of dollars continues to pour into renewable energy technologies. All considered, one might get the impression that global society is on the cusp of moving from a petro-market civilization to a post-carbon civilizational order fuelled by various forms of renewable, green and clean energy. The counter-evidence, however suggests otherwise. First, let us consider the capitalization of the renewable energy industry. At present, there is not a single firm in the Global FT 500 and the capitalization of the industry is an order of magnitude - trillions, not billions-lower than the oil and gas industry. Since the only sector of the global political economy that could potentially rival or overtake the fossil fuel industry is the renewable energy industry, we ought to be concerned with how investors anticipate the differential earnings potential of renewable energy firms. The evidence in Figure 14.5 is sobering and suggests that investors are nowhere near bidding up expectations. In fact, had investors capitalized the renewable energy index, their return on investment would have been $-6 \%$ over the period. In other words, as an investor, you would have deaccumulated relative not only to the oil and gas industry (about a 7\% return from 2007 to 2014) but also the broad S\&P 500 index which returned $9.2 \%$ over the period. The general problem across the industry is that it is capital intensive and its earnings are either too low compared to the returns of other firms and sectors of the global economy or they are non-existent. As the International Energy Agency's (IEA) recent report on renewable energy states "the capital-intensive nature of projects can make the risk/return profile of such assets challenging for investors" (2014b: 8). At the moment the risk/return ratio appears to be very challenging since we know that investors are ultimately concerned with differential accumulation. Though Marx mistakenly anchored his theory of accumulation in the labour theory of value, he did understand that, "use-values must therefore 
never be looked upon as the real aim of the capitalist; neither must the profit on any single transaction. The restless never-ending process of profit-making alone is what he aims at" (1887: 105). In other words, what matters most to capitalists is the accumulation of money and the renewable energy industry is nowhere close to showing monumental returns that would warrant trillions in capitalization. To be sure, this could change, but there are even more signs that compound the obstacles for a thriving post-carbon order founded on renewable industry. First, for the foreseeable future there is important evidence to suggest that current forms of high-energy social reproduction cannot be sustained with known sources of renewable energy. At best, renewable energy may move from making up about $19 \%$ of global final energy consumption to a little less than $30 \%$ of the world's energy consumption in the 21st century (Trainer 2007; Heinberg 2009; Smil 2011; REN21 2014: 13; Zehner 2012). Second, fossil fuel subsidies continue to be in the hundreds of billions of dollars yearly, dwarfing the investment made to the renewable [AU12] energy industry by a factor of four (IEA 2014: 4). In 2013, the oil and gas industry received US $\$ 550$ billion in subsidies while the renewable energy industry garnered a mere US $\$ 120$ billion in global subsidies. What this suggests is that-on the whole-governments continue to favour the oil and gas industry over renewable energy. To be sure, some governments are more actively involved in promoting greener and cleaner energy but at the moment, not a single nation in the G7, let alone the OECD consumes the majority of its power from non-renewable fuels. The IEA, the authoritative body set up to monitor world energy stocks and flows, anticipates that fossil fuels will continue to make up the majority of energy consumption in the rich world for most of this century. Even in Germany, where the political leadership has demonstrated a strong concern for energy conservation and renewable energy, we still find total final energy consumption consists of $83 \%$ fossil fuels with a goal to reduce this total only slightly by 2020 (IEA 2013: 119). If this is not enough to demonstrate the uphill challenges faced by the renewable energy industry and the fact that global society continues to be locked into an uneven and hierarchical carbon energy order, there is even more evidence to weigh when we think about the transition to a post-carbon energy future. Though I cannot go into detail here and note that this is not an exhaustive list, some of the main concerns to be found in the transition literature are as follows:

- Reliability as some sources are irregular (e.g. wind and tides)

- The potential for scalability (e.g. wind turbines and solar cells)

- The conversion of fertile land to wind farms and/or biofuels (e.g. the loss of food crops) 
- Negligible or negative energy returned on energy invested (e.g. some biofuels)

- Integration into pre-existing power infrastructure (e.g. electricity generated by wind)

- The inefficiency of battery storage (e.g. the loss of energy during conversion)

- The high price of renewable technologies (e.g. the price point of photovoltaic solar cells)

- Components made with commercially exhaustible and costly rare Earth elements (e.g. gallium and indium used in solar cells)

- Low winter insolation, dust and water vapour and clouds (e.g. photovoltaic solar cells)

- Capital-intensive investment (e.g. wind turbines, solar cells, research and development) (adapted from Di Muzio 2015b drawing on Trainer 2007; Heinberg 2009; Smil 2011; Zehner 2012).

Thus, if we weigh the evidence, it would appear that the oil and gas companies-publically and state owned-have the collective power to continue to shape and reshape the social reproduction of the world energy order going forward. Given our knowledge of the likely consequences of climate change, it may be appropriate to ask why this power is permitted to continue and why governments across the world do not simply mandate that fossil fuel resources remain in the ground to safeguard future generations. From the perspective of critical political economy, a potential answer is fourfold and only briefly elaborated on here. First, the dominant logic of business and governments is not livelihood or sustainability but differential capitalization and the pursuit of economic growth. Both require tremendous amounts of carbon energy to achieve. In the present environment, thinking about a leading politician running on an electoral platform of degrowing the economy is just as absurd as imagining a corporate $\mathrm{CEO}$ announcing that the firm she oversees will have the goal of accumulating fewer earnings this quarter than the last. Second, there is a certain degree of path dependence and what I will call here "path expectation". In terms of fossil fuels, path dependence essentially means that the construction of a more global petro-market civilization leads to energy intensive modes of living and that these modes of living combined with the drive to accumulate social power in the form of money necessitate evermore carbon energy for growth. For example, every new suburb created is an architectural testament to greater future energy intensity insofar as these ecosystems are built around the single family dwelling and automobility. What I mean by path expectation is simply the idea that additional governments and 
their citizens may find it highly desirable to embark upon a path towards high420 energy intensive living as the Chinese, Indians and Brazilians have recently done. Indeed, not only have these three countries seen accelerated growth in the last 20 years, but also increased energy consumption, altering the world energy order (de Graaff 2012). Realizing these expectations in material form is now leading to greater carbon energy path dependence in more countries. For instance, as a collective, non-OECD countries are now the primary consumers of total final energy consumption, a trend only recently broken (BP Statistical Review 2014). Third, the temptation to monetize the remaining economically exploitable fossil fuels on the planet may be too great. Most traders and investors envision a time when demand will finally outstrip supply and prices will skyrocket to unforeseen levels. If this happens, one can bet that both the earnings and capitalization of the oil and gas (and likely coal) firms will also skyrocket. A few stand to gain immense amounts of money by monetizing the destruction of the world's biosphere. Last, at the moment there are no large-scale energy alternatives and any post-carbon society is likely to have to form new social relations, new methods of production, logic and thought, new ways of governing and new indicators to govern social reproduction. It may be the case that it is simply easier to follow on the same ruinous course and hope that market forces will somehow sort out a reasonable future. Either way, this will be a Herculean task not made any easier the more societies and governments delay actively transitioning to a low carbon energy regime. There are certainly spaces of hope to point to but at the moment, they are largely marginal. A final consideration from the perspective of critical IPE is the relationship between carbon energy, violence and world order.

421

422

423

424

425

426

427

428

429

430

431

432

433

434

435

436

437

438

439

440

441

442

443

444

445

\section{Energy, Violence and World Order}

Before the transition to settled agriculture and animal husbandry, most anthropologists argue that our hunting and gathering ancestors were relatively egalitarian (Boehm 2001). This is not to project some utopia back into the ancient past but to recognize that with the rise of settled agriculture and cities, the social division of labour became more diversified and considerably more hierarchical, with a dominant caste typically appropriating social surpluses where the first major civilizations arose. Coinciding with this transition was the eternal recurrence of slavery and other forms of labour servitude. Though forms of slavery and servitude certainly differed historically and geographically, what they all have in common is that a minority of very powerful people used their slaves and servants as human energy converters to support
446 447 448 449 450 451 452 453 454 455 456 
their own affluent social reproduction. As late as 1772, the British agricultural writer Arthur Young (1741-1820) estimated that of a world population of 775 million, only 33 million could be categorized as in any way "free". The remainder, some 742 million existed in countless forms of servitude to the $4.3 \%$ of the world's population living as privileged dominators (Nikiforuk 2012: 12). One of the most violent and devastating examples of this search for exploitable human energy was the centuries-long transatlantic slave trade with an estimated 12 million people forcibly removed from their ancestral homes in Africa and transported to the "New World" where they would work under brutal conditions for the differential accumulation of the plantocracy (Blackburn 2010: 3). Though illegal slavery and various forms of labour servitude persist, there is some reason to suggest that with the revolution in fossil fuel energy and the mass introduction of machines, space could be opened up for slavery's abolition (Bales 2012; Mouhot 2011; Nikiforuk 2012). Though there were precursors, a comprehensive treaty to ban the international slave trade was not realized until 1890 and it was only in 1926 when a ban on slavery itself was initiated. But the interconnections between the apparatus of violence used to capture and socially reproduce "New World" slavery and the wealth and unequal power of the European-led world order it helped create and recreate is also mirrored in the present global energy order of fossil fuels - with oil by far the most important of the three majors.

Fossil fuels have always been connected with international violence and imperial power and can be traced to the rise of the first military-industrial complexes in the USA and Europe. By the 20th century, the two powers that created the most powerful means of destruction on earth - the USA and Soviet Union-were both awash in domestic oil. While there is much to say about this, we must restrict ourselves to a few comments here. The first comment is to realize that after World War I, the first mechanized or total war, virtually all military and governing officials realized that oil was essential to "modern warfare and industrial life" (Lewis 1921: 357; Yergin 1991). Difficulties in obtaining oil meant certain defeat as was also reinforced in the slaughter of World War II when Germany and Japan's quest for oil faltered and the Allies drifted to victory on a sea of US oil (Friedrichs 2010; Hayward 1995). The second comment is that while the Soviet Union enlarged its sphere of influence after World War II and used its domestic oil to industrialize, build up its means of destruction and for strategic international purposes, it was the USA and the international oil companies that largely organized the international oil order. Many believe that this order is currently changing but I think it is safe to argue that the fount and matrix of the global oil order was and remains US military might and the US dollar, the numéraire for virtually all oil sales 
not to mention other major commodities (de Graaff 2012). However, oil is not like any other commodity. As the war veteran Stan Goff argued: "Oil is not a normal commodity. No other commodity has five US navy battle groups patrolling the sea lanes to secure it" (cited in Clark 2005: 33). But while the US armed forces may be conceived as a global protection racket for "US" interests, from the capital as power perspective, we move away from methodological nationalism and consider how energy conflicts may actually benefit particular groups while causing great harm to many. From a critical political economy perspective, Nitzan and Bichler (1995, 2002, 2006; see also Bichler and Nitzan 2004, 2014) have done the most to shed light on how energy conflicts relate to the differential profitability of the leading oil firms. Readers are strongly encouraged to consult their works as I can only highlight one of their most important insights here: the fact that-with only one exception-every time that the differential earnings of the leading oil and gas companies trailed the average returns of the Fortune 500 companies, there were subsequent conflicts in the Middle East that restored the differential profitability of the oil and gas majors. ${ }^{5}$ Readers can consider for themselves whether this relationship is merely a coincidence or a pattern based on the oil and gas companies using their power and influence to shape government policy and encourage conflict to boost their earnings. While we may never know for certain without greater investigation, there can be little doubt that the relationship exists. A quick glance at Figure 14.5 already suggests that the "war on terror" was immensely profitable for the oil and gas industry as a [AU13] whole. Figure 14.7 shows the increase in overall capitalization of the oil and gas industry listed on the FT Global 500 from the start of the "war on terror" and charts this with the yearly share price of ExxonMobil and Chevron, the two US oil and gas majors. ExxonMobil's capitalization increased by $136 \%$ while Chevron trailed a bit behind at $122 \%$. Not a bad return for the dominant owners invested in oil and gas throughout the "war on terror" when we consider that the S\&P 500 index provided only a 7\% return to investors over the course of the war. There is little question that more spade work must be done to investigate the links between violence in the Middle East and US Grand Strategy as it pertains to energy and the future of world order. There is also much work to be done on the shifting global energy order and how this is connected to differential accumulation. And while analysis must go deeper into the politics and institutional power of the men (and they are typically

\footnotetext{
${ }^{5}$ Whilst there were no major Middle Eastern conflicts in 1996, the US did launch a series of cruise missile strikes during the Kurdish Civil War that year in northern Iraq.
} 
men) who seek to shape and reshape the world by monetizing oil and arm, a strong starting point is to focus on the battle for differential accumulation.

\section{References}

Altvater, E. (2007). The social and natural environment of fossil capitalism. In L. Panitch \& C. Leys (Eds.), The socialist register 2007: Coming to terms with nature. London: Merlin Press.

Bales, K. (2012). Disposable people: New slavery in the global economy. Berkeley: University of California Press.

Barry, J. (2012). The politics of actually existing unsustainability: Human flourishing in an climate changed, carbon constrained world. Oxford UK: Oxford University Press.

Bichler, S., \& Nitzan, J. (2004). Dominant capital and the new wars. Journal of World-Systems Research, 10, 255-327.

Bichler, Shimshon., \& Nitzan, Jonathan. (2014). Energy conflicts and differential profits: An update. http://bnarchives.yorku.ca/415/2/20141000_bn_energy_conflicts_and_differential_profits_web.htm. Accessed 3 Mar 2015.

Blackburn, R. (2010). The making of New World slavery: From the Baroque to the Modern, 1492-1800. London: Verso.

Boehm, C. (2001). Hierarchy in the forest: The evolution of egalitarian behavior. Cambridge, USA: Harvard University Press.

BP Statistical Review of World Energy. (2014). http://www.bp.com/en/global/corporate/about-bp/energy-economics/statistical-review-of-world-energy.html. Accessed 27 Mar 2014.

Brand, U., \& Wissen, M. (2013). Crisis and continuity of capitalist society-nature relationships: The imperial mode of living and the limits to environmental governance. Review of International Political Economy, 20(4), 687-711.

Bromley, S. (1991). American hegemony and world oil: The industry, the state system and the world economy. Cambridge: Polity Press.

Bromley, S. (2005). The United States and the control of world oil. Government and Opposition, 40(2), 225-255.

Clark, W. R. (2005). Petrodollar warfare: Oil, Iraq, and the future of the dollar. Gabriola Island: New Society Publishers.

Colgan, J. D. (2013a). Fueling the fire: Pathways from oil to war. International Security, 38(2), 147-180.

Colgan, J. D. (2013b). Petro-aggression: When oil causes war. Cambridge, UK: Cambridge University Press.

Colgan, J., Keohane, R., \& Van de Graaf, T. (2012). Punctuated equilibrium in the energy regime complex. Review of International Organizations, 7, 117-143.

Cox, R. W. (1987). Production, power, and world order. New York and London: Columbia University Press. 
Crosby, A. (2006). Children of the sun: A history of humanity's unappeasable appetite for 572 energy. New York: W.W. Norton.

de Graaff, N. (2012). The hybridization of the state-capital nexus in the global energy order. Globalisations, 9(4), 531-545.

Debeir, J.-C., Deléage, J.-P., \& Hémery, D. (1991). In the servitude of power: Energy and civilization through the ages. London: Zed Books.

Di Muzio, T. (2011a). The liberal renaissance and the ends of history. Journal of International Relations and Development, 15(2), 158-176.

Di Muzio, T. (2011b). The crisis of petro-market civilization: The past as prologue? In S. Gill (Ed.), Global crises and the crisis of global leadership (pp. 73-88). Cambridge, UK: Cambridge University Press.

Di Muzio, T. (2012). Capitalizing a future unsustainable: Finance, energy and the fate of market civilization19. Review of International Political Economy, 19(3), 363-388.

583

584

Di Muzio, T. (Ed.). (2014). The capitalist mode of power: Engaging the power theory of value. London/New York: Routledge.

Di Muzio, T. (2015a). The 1\% and the rest of us: A political economy of dominant ownership. London: Zed Books.

Di Muzio, T. (2015b). Carbon capitalism: Energy, social reproduction and world order. London: Rowman Littlefield.

Di Muzio, T., \& Robbins, R. (2015). Debt as power. London: Bloomsbury.

Di Muzio, T., \& Ovadia, J. (Eds.). (2016). Energy, capitalism and world order. Palgrave Macmillan: Basingstoke.

Elhefnawy, N. (2008). The impending oil shock. Survival, 50(2), 37-66.

Fix, B. (2014). Rethinking economic growth theory from a biophysical perspective. New York: Springer.

596

Friedrichs, J. (2010). Global energy crunch: How different parts of the world would react to a peak oil scenario. Energy Policy, 38, 4562-4569.

Friedrichs, J. (2013). The future is not what it used to be: Climate change and energy scarcity. Cambridge: MIT Press.

Goldthau, A., \& Witte, J. M. (2013). The role of rules and institutions in global energy. In A. Goldthau \& J. M. Witte (Eds.), Global energy governance: The new rules of the game (pp. 1-24). Washington, DC: Brookings Institution Press.

Hancock, K. J., \& Vivoda, V. (2014). International political economy: A field born of the OPEC crisis returns to its energy roots. Energy Research \& Social Science, 1, 206-216.

Hayward, J. (1995). Hitler's quest for oil: The impact of economic considerations on military strategy, 1941-42. The Journal of Strategic Studies, 18(4), 94-135.

Heinberg, R. (2009). Searching for a miracle: Net energy limits and the fate of industrial 610 society. (Forum on Globalisation and Post-Carbon Institute). http://www.postcar- 611 bon.org/report/44377-searching-for-a-miracle. Accessed18 Aug 2013 . 612

IEA. (2013). Germany: 2013 review. France: IEA. 613

IEA. (2014a). World Energy Outlook, 2014. France: IEA. 614 
IEA. (2014b). Renewable energy medium term market report. France: IEA.

Ikenberry, G. J. (1986). The irony of state strength: Comparative responses to the oil shocks in the 1970s. International Organization, 40, 105-137.

Jahn, B. (2013). Liberal internationalism: Theory, history, practice. Basingstoke: Palgrave Macmillan.

Kempf, H. (2008). How the Rich are Destroying the Earth (trans: Thatcher, Leslie). Foxhole: Green Books.

Keohane, R. O. (1978). The International Energy Agency: State influence and transgovernmental politics. International Organization, 32, 929-951.

Keohane, R. O., \& Victor, D. G. (2013). The transnational politics of energy. Daedalus, 142, 97-109.

Klare, M. (2002). Resource wars: The new landscape of global conflict. New York: MacMillan.

Klare, M. (2004). Blood and oil: The dangers and consequences of America's growing dependency on imported petroleum. New York: Metropolitan Books.

Klare, M. (2009). Rising powers, shrinking planet: The new geopolitics of energy. New York: Holt.

Lewis, J. O. (1921). America's petroleum problem. Journal of the Franklin Institute, 191(3), 357-379.

Marx, Karl. (1887). Capital: A Critique of Political Economy Volume 1 (trans: Moore, S., \& Aveling, E.). Moscow: Progress Publishers

Mouhot, J.-F. (2011). Past connections and present similarities in slave ownership and fossil fuel usage. Climate Change, 105, 329-355.

Nitzan, J., \& Bichler, S. (1995). Bringing capital accumulation back in: The weapondollar-petrodollar coalition-military contractors, oil companies and Middle East 'energy conflicts'. Review of International Political Economy, 2(3), 446-515.

Nitzan, J., \& Bichler, S. (2002). The global political economy of Israel. London: Pluto Press.

Nitzan, J., \& Bichler, S. (2006). New imperialism or new capitalism? Review, 29, $1-86$.

Nitzan, J., \& Bichler, S. (2009). Capital as power: A study of order and creorder. London: Routledge.

Nore, P., \& Turner, T. (Eds.). (1980). Oil and class struggle. London: Zed Press.

Podobnik, B. (2006). Global energy shifts: Fostering sustainability in a turbulent age. Philadelphia: Temple University Press.

REN21. (2014). Renewables 2014 Global Status Report. Paris: REN21 Secretariat.

Smil, V. (1994). Energy in world history. Boulder: Westview Press.

Smil, V. (2006). Energy. Oxford: Oneworld Books.

Smil, V. (2011). Energy: The latest infatuations. American Scientist, 99(3), 212-216.

Spiro, D. E. (1999). The hidden hand of American hegemony: Petrodollar recycling and international markets. Cornell: Cornell University Press. 
Stoddard, E. (2013). Reconsidering the ontological foundations of international 658 energy affairs: Realist geopolitics, market liberalism and a politico-economic alter- 659 native. European Security, 22(4), 437-463. 660

Stokes, D., \& Raphael, S. (2010). Global energy security and American hegemony. 661 Baltimore: Johns Hopkins University Press. 662

Trainer, T. (2007). Renewable energy cannot sustain a consumer society. New York: 663 Springer. $\quad 664$

Yergin, D. (1991). The prize: The epic quest for oil, money and power. New York: Free 665 Press.

Zehner, O. (2012). Green illusions: The dirty secrets of clean energy and the future of 667 environmentalism. Lincoln: University of Nebraska Press. 


\section{Author Queries}

Chapter No.: $14 \quad 14$

\begin{tabular}{|l|l|l|}
\hline Queries & Details Required & Author's Response \\
\hline AU1 & Please check if author name and affiliation are okay. & \\
\hline AU2 & Please specify "a or b" for Di Muzio (2015). & \\
\hline AU3 & Please check if identified head levels are okay. & \\
\hline AU4 & Expand LDC in full. & \\
\hline AU5 & $\begin{array}{l}\text { According to the text this Figure is for the developed countries, so } \\
\text { explain this in the caption to distinguish from Figure 14.2? }\end{array}$ & \\
\hline AU6 & $\begin{array}{l}\text { The citations "James Hansen et al. 2013, Nikiforuk 2012, UNDP } \\
\text { (2000)" are not listed in the reference list. Please check and } \\
\text { provide the details or delete the citations. }\end{array}$ & \\
\hline AU7 & $\begin{array}{l}\text { Stoddard (2015) has been changed to Stoddard (2013) as per } \\
\text { reference list. Please check if okay. }\end{array}$ & \\
\hline AU8 & $\begin{array}{l}\text { Fix (2015) has been changed to Fix (2014) as per reference list. } \\
\text { Please check if okay. }\end{array}$ & \\
\hline AU9 & Change OK and intended meaning retained? & \\
\hline AU10 & Change OK as the abbreviation in the text is in capitals? & \\
\hline AU11 & $\begin{array}{l}\text { There is reference to a Figure 14.7 in this chapter but there is no } \\
\text { Figure 14.7 listed here. Please include caption for Figure 14.7. }\end{array}$ & \\
\hline AU12 & Please specify "a or b" for IEA (2014). & $\begin{array}{l}\text { There is no caption for Figure 14.7 in this chapter. Please provide. } \\
\text { Or rather do you mean Figure 14.6 instead here? }\end{array}$ \\
\hline AU13 & $\begin{array}{l}\text { Reference "Di Muzio and Robbins (2015)" is not cited in the text. } \\
\text { Please check. }\end{array}$ & \\
\hline AU14 & & \\
\hline
\end{tabular}

